\title{
Unlocking Africa's Economic Heart
}

\author{
John W. Forje $\mathrm{e}^{1}$ \\ ${ }^{1}$ Post Box 85, Bali Nyonga, Bali Sub Division, Mezam, NWR, Cameroon Republic \\ Correspondence: John W. Forje, Post Box 85, Bali Nyonga, Bali Sub Division, Mezam, NWR, Cameroon Republic
}

Received: November 3, 2016

Accepted: May 11, 2017

Online Published: May 15, 2017

doi:10.5430/bmr.v6n2p17

URL: https://doi.org/10.5430/bmr.v6n2p17

\begin{abstract}
In spite of its resources potential, Africa remains the least developed continent on Planet Earth. The paper props into issues promoting or inhibiting the sustainable transformation of the region. It does so by critically unleashing fundamental issues delaying its transformation nexus. The geo-construct of these landlocked states calls for specially designed economic approach to respond to a set of socio-political and economic developments on the continent for over 500 years. European colonialism influenced the pattern of governance of African countries and they continue to do so in several of these states. Colonialism established ruling hierarchies and entrenched forms of poor citizenship which were both blatant (as under apartheid), but also subtle (as in forms of Orientals). Colonialism also produced ways of knowing and meaning-making, which imposed particular forms of reasoning and, at the same time, marginalized or silenced alternative ways of understanding the world. Western colonialist domination imposed an artificial backwardness on African countries and her people. It caused both an abnormal stagnation of cultural development and even cultural retrogressions. The effects of these western-centred influences on developing nations have been a 'set of facts'. These 'facts' are widely employed as evidence that purportedly proves certain delusions Africa is poor because it is poor to begin with. Therefore, the paper has two objectives, (i) to discredit and discard widely held delusions concerning the poverty of the continent, delusions widely spread among both European and African circles; and (ii) in place of those delusions, supply an applicable set of policies, made comprehensively for practical realization of the sustainable transformation of Africa. It adopts a progressive Afrocentric approach rather than the Eurocentric development strategy that has dominated the economic transformation of the continent for ages. Poor governance backed by poor leadership remains the underlying factors of the continents underdevelopment. A sea of confusion clouds the socioeconomic transformation of the continent. The focus of the paper is on African states in general and in particular landlocked states, leadership and resources use in the transformation of the continent so that the people benefit from natural resources. As such, the paper examines the narratives (positive and negative) emerging from the OBOR and FOCAC offensive for Africa which equally challenges that of Western Europe which has for long seen its role as hegemonic and unquestionable. Theoretically and empirically, the analysis concerns challenging clashing world views and perceptions having implications for the continent's transformation China's engagement in Africa. It is clear that countries on the coast line are of advantage, the existence of poor leadership can equally be a curse to these countries. The cases of Nigeria and Cameroon illustrate a good example (Omotola 2006; Forje 2011; Asonganyi 2015). Putting western influence in Africa to one side, how do we aid Africans in achieving the most rapid realization of the people's mental potentialities, for mastering the advanced technologies? African industry and agriculture urgently require improving the welfare of the people?
\end{abstract}

Keywords: Integration, Economic growth, Land locked states, Good governance, Leadership, Free trade, Market economy, Corruption, Infrastructure, Trade, Quality of livelihood

\section{Introduction: Unleashing Potentials for Transformation}

"A people without a positive history are like a vehicle without an engine. They always live in the shadows of a more successful society"

[Steve Biko]

Africa's 54 states are bedeviled with many potentials as well as obstacles related to the state of socio-economic transformation. Some are landlocked, with or without resources; delays and bureaucratic red tapes; some have built-in trading disadvantage such as high transport costs, poor governance and other obstacles inhibiting economic growth of these countries. Yet the underlying factor that sentences the continent to perpetual underdevelopment is bad governance and poor leadership including other factors such as internal political conflicts, wars between states 
ethnical dispute, corruptions, among others.. To this can also be added external factors that can be overcome through the practice of good governance, unity and the determined resilience of the people to improve on their wellbeing. The integration and unity of the people provides the requisite anvil of increasing economic development and prosperity, education, health care and political stability in Africa. Yet, looking at the present situation of the continent, the question arises, "is this a realistic option? Is Africa not a continent in crisis, whose future will be characterized by economic instability, famine, political confusion, unrest and continuous ethnic or even regional wars?

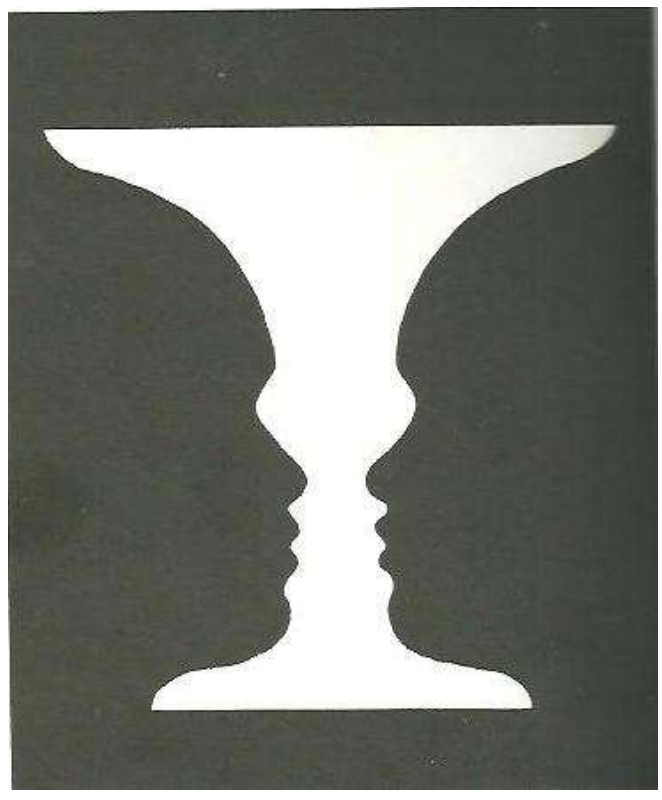

Figure 1. Looking into the African Crystal

Ball for the Sustainable Development of the Continent

Source: Credit Bandmann Hans (1980). "Opening Address to the FEF Conference on the Industrialisation of Africa". In Fusion Energy Foundation (1980). The Industrialisation of Africa. Campaigner Publications, Wiesbaden, Germany.

Contextualising the African continent in genuine socio-economic transformation terms, we can do so from essentially two different analytical standpoints, namely; (Eurocentric which builds on the concept of 'Free Trade' or 'Free Market Economy' with the ground work long laid by Adam Smith school of thought; and the other, Afro-centric, strongly grounded by Nkrumah and a host of others as the practical basis for the political and economic independence and sovereignty of the continent. Depending on which of these two different conceptual approaches one takes, one arrives at different conclusions as the present state and future prospects of the continent. The significance of this is best captured by an ambiguous illustration presented here (Fig 1: Looking into the African Crystal Ball).

What first attracts you looking at the picture is a vase; yet at the same glance the heads of two persons looking at each other. The primary cause for your alternating perception lies in your mental effort synthesising the various features of the picture into a definite gestalt. Once you have comprehended that your perception is a function of your mental activity, it is possible for you to shift, by a small mental effort, your point of view to the one or the other perception (Bandmann 1980:10). Having the right mindset, common and collective mentality efforts lead to conceptualising the right solutions to the socio-economic and political economic problems of the continent. For now, the continent seems to be condemned to the ghetto of poor quality livelihood. There is need for developing a 'grand design' for the integration and industrialization of Africa.

Africa and the rest of the world are looking at each other in conceptualising the economic and political problems of the continent in such away that we come to a conceptual starting point for considering the development of Africa. It is also within this context that 'landlocked African countries' and 'coastal states' are looking at each other to create the enabling environment and perspective of increasing free movements of persons and goods; to usher prosperity and political stability for the sustainable development of Africa. The vase is the crystal ball Africans must look into, 
sought out their differences/predicaments and articulate a common policy strategy and implementation action plan to advance a progressive Afro-centric developmental approach. Such a new plan of action should ensure a new approach to the education of citizens and building their capacity and workforce, a cultural renaissance or the technical aspects of articulating and implementing a forward-looking strategy for developing Africa.

Therefore, the poor and rich, the urban and rural areas should be looking at each other with the goal of ensuring balanced development, equity in benefit-sharing as the right approach to the new economic perspective for Africa. What des the two different approaches - Eurocentric and Afro-centric concretely mea for the economic and political perspectives for Africa? The publication, Africa in the 1980s: A Continent in Crisis (Legum and Zartman, 1979) directly or indirectly show-case the Eurocentric and Afro-centric undercurrents reflecting some of the issues addressed here. The economic crisis of the 1980s (Structural Adjustment Programmed-SAP) was a deliberate ploy that Africa is not worth the development and industrialization. This was a tacit comprise by the West that Africa should be left as ghetto to fight its battles. In short, constructed/comprehensive development should not see daylight in the region.

It was a French politician who remarked in the 1930s; "there are no crises in Africa, they only serve as an excuse for those who do not want to leave the old track' (Legum and Zartman, 1979). To take up the challenge of its underdevelopment, Africa must open up the interior and link with the coastal regions to facilitate its industrialisation nexus. Only by linking the coastal region with the interior that a new Africa can be discovered to face current challenges. Such a linkage and industrialisation will give it a new kind of riches and fertility as well as improved welfare. Africa will no longer be thrown into the ghetto. A successfully implemented grand Afro-centric design linkage and industrialisation under united coordinated policy concepts will change the face of the continent for the better. The need for an African New Order (ANO) can no longer be emphasised. African countries apart from adopting their national development plans should link it to the AU Agenda 2063 and UN Agenda 2030

The paper stresses the fact that poor governance and served leadership in fragile states, among other relevant factors, underscores the main problems limiting the sustainable transformation of the continent. Conversely, good governance and leadership, among other factors, offers a more realistic approach in transforming the continent and improving the welfare of citizens. It should also be noted that good governance (GG) and economic development (ED) are impeded by weak public institutions because public institutions are weak (Rothstein \& Teorell, 2008) in these countries dominated by an all powerful served leaders. The continent is in urgent need of servant leaders out to serve the people and not to be served. Thus, a servant leader is one who knows the way, goes the way, and shows the way, using all public resources available with this aim. Therefore, as captain (s) he looks for results not salutes. The paper shows that the necessary dimensions of an industrialisation of Africa and the problems which result from that must be Afro-centric. Only through an Afro-centric development agenda can Africa concretize what an economic policy approach based on the 'industrial system' means for Africa, as opposed to the current Eurocentric approach dominating the discussions on 'development' strategies for Africa. The basic consideration is this: the basis of all economic consideration is the population in its development-dynamic. Development has to be people-oriented and focused on constantly improving on the welfare of citizens.

Some seventy or more years ago, China was one of the poorest countries in the world, populated mostly by rural peasants, and still suffering from more than a century of internal turmoil and international humiliation, and military occupation by foreign countries. Today China is a rapidly modernising economic dynamo with growing global influence. Africa can with good governance and visionary leadership accomplish the same form of development (Nye 2010; Joseph (ed.) (2010). China for example has lifted people out of poverty than anywhere else in the world: its per capita income increased five-fold between 1990 and 2000, from USA $\$ 200$ to USA $\$ 1,000$. Between 2000 and 2010 , per capita income also rose by the same rate, from USA $\$ 1,000$ to USA $\$ 5,000$, moving China into the ranks of middle-income countries. Between 1990 and 2005, China's progress accounted for more than three-quarters of global poverty reduction and is the reason why the world reached the UN Millennium Development Goals (MDGs) of halving extreme poverty. This incredible success was delivered by a combination of a rapidly growing labour market, driven by a protracted period of economic growth, and a series of government transfers such as the above urban subsidy, and the introduction of a rural pension (Stuart, 2015). Furthermore, an important element that needs to be considered is the adoption of a correct economic policy by the government putting aside the political/ideological control of the economy.

Looking at the crystal ball (Fig 1), the African situation depicts a sorrowful picture. For example, the Goldman Sachs in a more up-to-date honest report on South Africa (one of Africa's economic giant) stated that 'South Africa is one of the most unequal societies in the world. By 2008, $85 \%$ of Africans were still in the impoverished or lower 
income categories, receiving less than R1,400 per month (USA $\$ 120$ ) compared to $87 \%$ of whites who occupied the middle and upper income categories. Unemployment too has barely moved from the $23 \%$ inherited in 1994 to a post-Apartheid average of $24.5 \%$. With $70 \%$ of the unemployed under 34 , the young are disproportionately affected. Job and export-creating mining and manufacturing almost halved their share of GDP to $23 \%$ since 1986, while banking and real estate doubled to 24\% (Commey 2015:48). Rapid population increase without corresponding economic growth and sustainable employment nexus impedes the transformation of the continent. The Chinese example should spur Africa to have an integrative and inclusive society, a productive and dynamic economy and sustainable welfare structure catering for all citizens. In short, only Africans can build up Africa.

The same picture can be painted of other African countries. How can a continent possessing most of the world's resources be the poorest and least-developed at the same time? This is because Africans have refused to own their resources. Above all, they seem to bath in the enchanted waters of their ignorance being their weakness. Thus, there is a common virus spreading across the length and breadth of the continent that must be arrested. The ignorance virus' must be eradicated without which progress cannot be made. So far, Africa remains the continent to explode, needing a little ignites to spark it and every thing will go into flames. Ironically, the people spend long periods defining who Africans are which is time wasting for the people but of great benefit to the rich while the real issues the dispossession of our poverty hangs over our heads remaining unresolved and undermining the sovereignty of the continent

Therefore, African governments must reduce inequality, empower women, increase employment, especially amongst the youth and defend the gains made so far. The way forward is to improve and increase public sector productivity output, efficiency and effectiveness. The challenges the continent faces, are that of race, ethnicity, class, poor human capital development, skills disparities, entrepreneurship deficits, immigration problems, poverty, unemployment, wrong use of resources and the lack of access to capital play major roles in making the continent poor in the wakes of plenty. This remains a deadly cocktail and why the continent must search for a new crystal ball to unlock its development deficiency. Interesting enough, the continent has the resources - human and natural - and even capital to do what needs to be done, yet it is not acting in that vein. Why? It is clear that a high degree of dissatisfaction with the pace of economic growth and inequality in the benefit or prosperity-sharing persist encouraging a tense political temperature, contestation and finger-pointing that gives rise to competing centres of power and loggerheads in society. Finger pointing as noted by (Mashamaite 2014) only divide rather than unite society. Unity, confidence and trust among African states will rapidly address the plight of landlocked countries as well as accelerate its transformation from an underdeveloped to a developed society. Afro-centric agenda is the 'blue-print' necessary for changing the economic and political conditions for the industrialization of Africa. Unless the face of Africa is comprehensively changed, the people will have no quality livelihood.

The greatest pride a continent has is its independence, social cohesion and strong economic growth under the canopy of good governance and rule of law. In unlocking its development predicament it equally needs an entrepreneurial and skilled human capital base (Juma 2015; Muchie 2015). Unfortunately, Africans worship everything foreign. To paraphrase Djanie (2015), Africans love everything foreign. Their love and worship for anything foreign helps in destroying their ability to progress as it entrenches and deepens their dependency. As a result, they hang on the 'blame' theory for their failure. The result is that they waste time defining things that should no longer be defined in the interest and benefit of the West rather than forging ahead for the benefit of Africa. The real issue facing Africa is dispossession of Africans and the glorification of the West - thus the cause of the continent's poverty - which remains unresolved.

In a chaotic and confused development environment, (like what exist in the African polity-space, change can only come from within and through a new mindset and the determination to brave all odds. Africa is yet to arrive; the entre society to produce sustainable development and this entails moving away from exporting raw materials to establishing industries. In short embracing the Afro-centric rather than the Eurocentric agenda is what the continent needs. It is envisaged that a progressive Afro-centric agenda properly executed denotes what UN Secretary-General coins, '2015 to be a year if transformation in leaving no one behind and ensuring lives of dignity for all." The Afro-centric agenda should be to end poverty and hunger, put an end to isolation and to achieve sustainable development goals (SDGs) in all totality through promoting inclusive economic growth protecting the environment and promoting social inclusion.

Interesting enough, Africa's landlocked states possess the bulk of Africa's natural wealth. Thus, unleashing their potentials (landlocked countries like empowering women and exploiting the prowess of youths) could transform Africa's socio-economic development. The continent has the resources but not the capacity to become and industrial 
entity. For now, the economy of African countries is diversified to a merely very slight degree. The extractive economic sectors still dominate, largely as a heritage from the colonial period, i.e. agriculture, forestry, fishing (to a slight degree), and mining. Agriculture often soaks up more than $70 \%$ of the total labour power of a country. Productivity in must economic sectors is extremely low; and, therefore, their contribution to the total economic net surplus is also low. This is primary due to insufficient human capital development, but especially due to lack of an efficient scientific and technological base (Fusion Energy Foundation 1980:84-5).

Not many African countries succeeded in attaining the Millennium Development Goals (MDGs) apart from Mauritius, Cape Verde, Rwanda, Botswana and Seychelles. The leaders are challenged to ensure the realisation of the call 'Africa's transformation' and the main African Union (AU) Development Strategy, Agenda 2063. If they have ever been a time to fight for the continent's economic independence is now, which means stopping exporting hides and skins, coffee, tea, cocoa and even crude oil and other materials in their raw form. For now, the biggest challenge remains how to process these raw materials and how to transport their exports and imports most effectively and efficiently with minimum cost and how to connect with other African countries. We must infuse the process of development and connectedness and grow to replace all the left-over refuse we carry into the initial phases of the present great undertaking. This is the key to fostering the most rapid advancement of the continent and deploying the powers of scientific and technological to accelerate Africa's economic development and quality livelihood for all.

The current economic model (Eurocentric agenda) which excludes value addition, is exploitation of the highest order and we cannot continue that way" (Kabukuru 2015). For Africa's transformation to be truly realized and millions lifted out of poverty a new push is needed to reach seven percent economic growth which requires developing and maintaining new infrastructures. That is why it is extremely important to unlock the continent's economic heart for sustainable development goals. Getting into the depth of the interior, creating access for free movements of people and goods and processing its natural resources remain vital for Africa's development.

\section{Methodological and Conceptual Approach}

The paper builds on secondary data, participant observation and discussions with a wide cross section of the population. To this is added the political, economical, social, technological, environmental and legal (PESTEL) and the SWOT analysis (strength, weaknesses, opportunities and threats) are used to determine the positive and negative potentials relevant for the continent in its transformation process indicating as well as some factors influenced by internal and external conditionality's. This is illustrated on Fig 2: PESTEL and Fig. 4: SWOT Analysis Map respectively [see Sofaniadi 2015:18]. The interrelationship or combination between PESTEL and SWOT, cost-benefit and socio-economic analyses illustrates the sustainable livelihoods framework which shapes the socio-economic analysis of African countries. The sustainable livelihoods framework demonstrates that vulnerability to poor resources use, poor infrastructural and institutional networks, bad governance and articulate served leadership, among others, will of course impact on the status of a society.

Institutional structures, processes and rule of law are necessary to improve on the value of livelihood - human, natural, financial, physical and social. These assets are vital livelihood drivers for improving quality of welfare for all. Good governance, servant leadership style is catalyst to sustainable development. The path to Africa's economic development and technological progress provides the indispensable environment in which to foster consciousness of scientific and technological transformation of the continent. Building the human capital of the people is developing the creative potentials of the individual mind. It is the sum total of this collective individual mind development under the state of good governance and rule of law that has the transforming mechanism for the region. Presently, it is a wishful delusion or thinking to speak of the development of Africa without committing ourselves to the replacement and eradication of factors of economic doctrines impeding the sustainable transformation of the continent. The question of landlocked African countries in particular and industrialisation of the region provides an occasion for replacing the Eurocentric model with a new approach. 


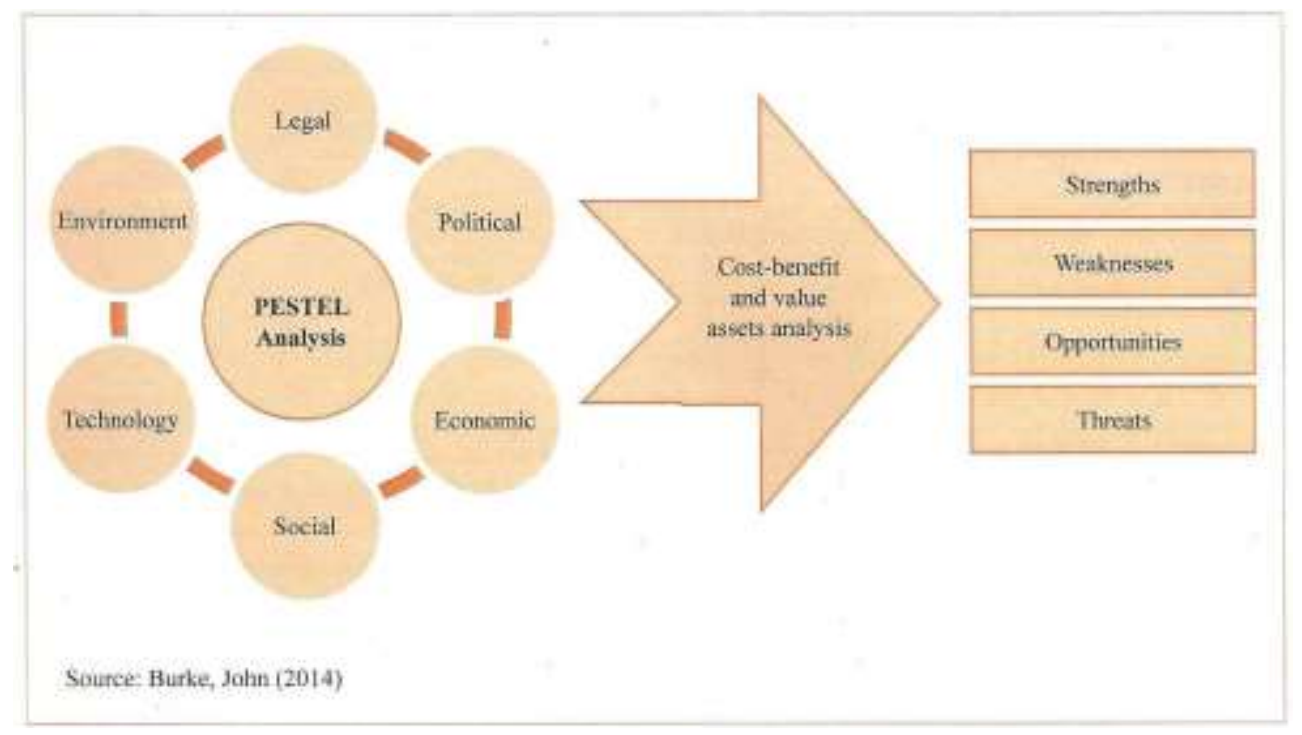

Figure 2. PESTEL and SWOT Analysis

A comprehensive combination of the PESTEL and SWOT show how the prowess of the continent lies through good governance and leadership which constructively change the face of Africa and its population within a generation. The dynamics of the economies have changed as landlocked countries face more obstacles and hurdles than their maritime neighbours. Growing political instability within coastal states makes the importation and exportation of goods extremely difficult. It is noted that transport costs for landlocked countries are as high as $77 \%$ of the value of exports. Unit costs of road transport in Africa are in the region of 40\%-100\% more than rates in Southeast Asia. The challenge is how to use PESTEL to improve on its status (strength and opportunities) and to wade off existing threats and weaknesses impeding the sustainable development of the region. Wading off the threat means putting together in a coherently pattern the political, economic, social, technological, environment, and legal implements as the driving force for attaining a sustainable society that is in harmony with itself and nature.

\section{The Relationship between Governance, Leadership and Development}

Many argue that good governance, leadership and development nexus of the 1990s, has evolved to be unrealistic, overloaded and too ambitious (Grindle, 2002). Others point to the rather technical approach often being imposed from outside (Chhotray \& Hulme, 2009) about the socioeconomic transformation of the continent. It is not a question of theory but improving the welfare of the people. Here Sachs (2015) notes that 'sustainable development is both a way of looking at the world with a focus on the interlinkages of economic social and environmental change, a way of describing our shared aspirations for a decent life, combing economic development, social inclusion and environmental sustainability.

What is required is a reconstituted best mindset rather than focusing on establishing and operating on the 'blame' theory. The post 2015 agenda or the Sustainable Development Goals (SDGs) should spur Africa towards a new engine of growth strategy - hence the emphasis on a progressive Afro-centric approach. Adopting the reality theory which establishes the constructive and progressive way forward for the linkages between good governance, leadership and development in unlocking Africa's economic heart is the better alternative. Of course, we cannot escape the realities of the peculiarities and essential difficulties of some African states - for example, landlocked or resources deficient countries or with internal unrest, affected by religious conflicts, or political and ethnic domination and instability. The Kenya-Uganda railway remains in tract with plans to extend the line to Kigali in Rwanda. In the colonial era, roads and railway lines led from the interior to the coast. In the vast Congo territory, Belgium used the might Zaire River to transport initially rubber, later copper and other minerals to sea outlets and thus transform itself from an impoverished state to a wealthy, powerful nation. Cecil Rhodes dream of 'opening up Africa' to the world by building roads and railway lines that connected the coast of Africa with the interior - the Cape-to-Cairo railway link that would have feeder branch-lines going east and west, north and south in each country should be kept alive with a difference.

The salient factor is that good governance, adherence to the basic tenet of democracy and leadership play important roles in transforming the socioeconomic status of a country. This can be supported from experiences in countries that 
are resources deficient but able to pull themselves out of the poverty nexus. Poor governance and leadership breeds a vicious circle of underdevelopment characteristic and political instability of contemporary Africa. Responding to the plight of the people, the continent needs to protect, adapt, relocate and progressively responding to the changing times under the great influence of advances in science and technology. Thus, PESTEL plus SWOT plus the late-comer advantage forms the constructive structural-base for Africa's transformation and ensuring a strong place within the globalization nexus of our time. Given that 'globalisation' is the highest stage of scientific imperialism (i.e. that is Western Advancement in Science and Technology) and with the continent's deficiencies in human capital development and industrial base, it cannot be a veritable player in harvesting the benefits of this new knowledge-based economy.

Taking the case of Africa's landlocked countries, [Botswana, Burkina Faso, Burundi, Chad, Central African Republic, Ethiopia, Lesotho, Malawi, Mali, Niger, Rwanda, Swaziland, Uganda, Zambia and Zimbabwe] these countries can be seen as least developed yet endowed with abundant resources potential. There are many reasons why landlocked countries are poor. To begin with, they are relatively isolated from the world even though advances in technology ushers greater communication connectivity among nations. The spread of telecommunications via the humble mobile phone and increasingly the Internet has greatly reduced the 'isolation factor' in landlocked countries. In the second place, distance from the sea entails extra costs, more complicated logistics, more bureaucracy, higher insurance premiums and more dependence on the goodwill and stability, of neighbours with sea outlets. For example, the civil war in Cote d'Ivoire impacted seriously on cotton exports from Mali and Burkina Faso.

Assuming Cameroon being an unstable polity, this would impact seriously on the economies of Chad and the Central African Republic. Botswana emerges as the star of the world's landlocked countries. It is the world's largest producer of gem-quality diamonds which, after refining, are negligible in volume but hold enormous value. These are transported to the world's buying centres by air. Like Zambia, Zimbabwe and South Africa, it also produces excellent beef, but getting this to markets abroad is a more expensive exercise. Zimbabwe holds the largest platinum reserves in Africa and is an important producer of gold and other minerals. Zambia is one of the world's major producers of copper. Mali, once the centre of the trans-Saharan trade, is slowly regaining its luster as one of the continent's important gold producers - although this time, the direction of travel for its export is towards the Atlantic rather than the Red Sea. Niger has the second largest reserves of uranium in the world. Chad has emerged as an oil producing country through a pipeline to the Atlantic coast via Cameroon. All these show the importance of rails, ports, roads and air transportation to the economy of the continent.

To disenclave these land locked territories, the construction of both a Trans-African Railway line and Road Communication network is essential. The development of the following, Fig.3: Projected African International Railway links are important; just as the importance of a comprehensive Trans-African Road (Cairo to Cape, Banjul to the Horn) network. In line with this are the urgent improvements in harbour infrastructures within the coastal states and improvements of river ways to ease the plight of landlocked territories. The construction of an interconnected continental rail network will help regions far from the coasts and locked countries will obtain effective connections to the ports, and thus to the world markets; international lines will connect individual national networks to each other, and will thus form the backbone of the economic and political unity of Africa.

\begin{tabular}{|llcc|}
\hline Trans Sahara Link & Fes-Bechar - Niamey & 2700 & $\mathrm{~km}$ \\
Atlantic Line & Makurdi-Douala-Kinshasa-L aunda-Windhuk & 4000 & $\mathrm{~km}$ \\
\hline Trans West Africa & St. Louis-Kankan-Parako-Ngaoundere-Bangui & 4400 & $\mathrm{~km}$ \\
The Cairo -Cape & Cairo-Cape line & 8000 & $\mathrm{~km}$ \\
\hline Trans Sahelien & Bamako-Niamey-N'Djamena-Nyala & 3600 & $\mathrm{~km}$ \\
West African Coastline & Dakar-Freetown-Abidjan-Lagos-Douala & 3800 & $\mathrm{~km}$ \\
Trans Centralafrica & Yaoundé-Bangui-Pakwach & 2400 & $\mathrm{~km}$ \\
Trans Eastafrican & Addis Ababa-Nairobi-Quelimane & 3600 & $\mathrm{~km}$ \\
Pacific Line & Mombasa-Da-Beira-Maputo & 3000 & $\mathrm{~km}$ \\
\hline
\end{tabular}

Figure 3. Suggested/Projected African International Railway Lines

Source: Forje (2015) compiled fro Fusion Energy Foundation (1980) The Industrialisation of Africa. 
The proposed railroad in West Africa [Benin, Burkina Faso, Cote d'Ivoire, Ghana, Niger, Nigeria and Togo] is expected to boost inter-regional trade as well as open up landlocked states like Burkina Faso and Niger to the coastal states. These countries depend on their neighbours' seaports and road infrastructure to move their exports and imports Fig 4: Proposed Railroad in West Africa show the cost of construction estimated at USA $\$ 58.9$ billion, covering a distance of $3,000 \mathrm{~km}$. It is expected the projected regional railroad network will speed up transit times for freight and reduce the prices of consumer goods for landlocked Sahelian countries such as Burkina Faso and Niger because most imported goods will be transported by trains.

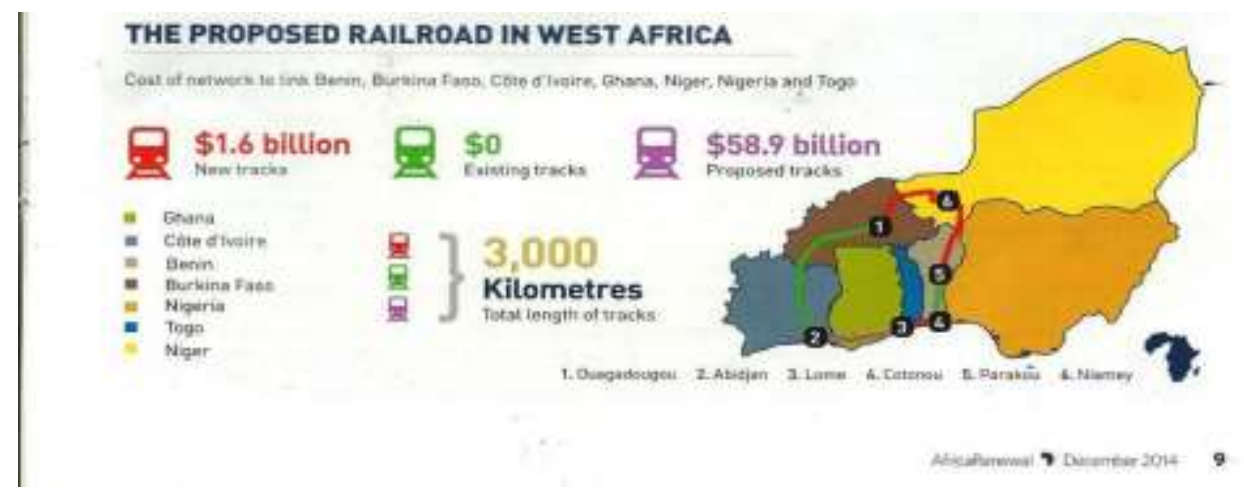

Figure 4.

Source: Kuwonu Franck (2014) West Africa: New Railway Network Aims to Boost Inter-regional Trade, New African, December 2014, p9

To facilitate the export of goods from the continent will equally require expansion of existing main ports and constructions of new ones. West, Central and Southern African countries have great potentials in ports construction. The most comprehensive construction harbor projects will be in Abidjan, Dakar, Lagos, Accra, Niger Delta, Limbe (Cameroon), Luanda, and Banana through which for example, the largest part of trade of inland states of Mali, Upper Volta, Niger, Chad, Central African Republic will be rooted. The navigation of rivers like Niger, Benue, Cross River, Nile, and Volta etc. will be great help to landlocked economies as well as the interior parts of countries. Improvements of Eastern and Southern African ports, Mozambique, Mombasa, Mtwara, Beira, Durban, Cape Town, Port Elizabeth, Massawa, etc. will supply a large inland region, the South of Sudan, East and South of Zaire, Zambia, Malawi, Zimbabwe. Egypt has already expanded the Suez Canal. The integration of the African population still living outside the nuplexes, together with a steady growth of exports and imports will increase the transportation of goods.

It means that their exports cost more to get on board ships and imports become more expensive. Within this context, it is even cheaper to transport goods from the United States and Europe, Nigeria, Cameroon, Ghana and Senegal than to move the same items from these countries to a neighbouring landlocked country. In short, the actual cost of transportation along Africa's trade corridors is no anywhere else higher than it is anywhere else in the world but the transport that the price of transport is the highest. Long delays, poor infrastructure, and above all, gross inefficiencies and bureaucratic red tape at the border crossings all conspire to make the movement of goods and people in Africa among the most expensive in the world. The lack of seaboard, ports and harbours, railway way lines and road infrastructures are a major constraint on the economic development of landlocked countries in particular, and the continent in general.

Airlines are significantly increasing their role of connecting countries and peoples, making long-distance travels easier and better. For landlocked African countries, airlines have been the saving grace. Countries like Ethiopia, Zambia and Malawi can airfreight their horticultural produce and flowers to virtually any destination in the world and still sell at high competitive prices. Apparently, Africa's regional integration is gradually picking up and transport corridors are reaching out to countries deep in Africa's hinterland. Many airlines are pushing up plans to link the entire continent by opening new routes. Once the whole of Africa is connected up, the sky is the limit for this incredibly rich continent. Africa's aviation industry is growing at $4.7 \%$, faster than any other region and passage numbers are expected to double to 300 million in the next two decades according to Brock, 2015. This increase is not 
an increase in domestic flight, opening the interior and linking it with the capital cities, except in countries like South Africa, Kenya, and Ethiopia.

The irony is that the greater share of the continent's natural resource wealth and its commodities lies in the landlocked countries (Dowden 2010). Why unlocking and unleashing Africa's potential is essential for the development and improving the welfare of citizens. In addition, inequality remains a big issue and must be tackled. Significant gender and regional inequalities, implying that governments need to do more to target women and people living in rural areas ( as well as other groups such as disabled) to ensure that no one or state is left behind. The governance and democracy structure needs to be revived (Knight et al 2002; Ake 1996; Forje, 2011). To stretch the issue further, equitable growth will of course need to be a sustainable kind that cuts across rather than increases the existing divide in society. Connecting the continent through proper infrastructural construct will ease the plight not only of the landlocked countries but equally accelerating development related activities within and between nations.

Old trade routes from ancient civilization of Great Zimbabwe to the shoes of Mozambique, from North Africa to the Atlantic coast of the Gulf of Genuine and other transport infrastructure across the continent should be developed. Without the construction of a modern transport and communication system the developed economies could not have attained the characteristics which today place them beyond all other nations. This close insoluble connection between industrial development and the building up of effective transport systems hold true for Africa: their can be real development unless massive infrastructural projects are made an integral part of the overall development process. No industrialization of Africa without infrastructure - it would be pointless repeating this obvious truth, if there did not exists certain circles and entrenched viewpoints which deny exactly such a connection.

The strategic approach of Eurocentric agenda is to retain Africa as suppliers of raw materials and possible markets for exports. The World Bank has not departed from that strategic orientation; Africa must be kept at the level of an underdeveloped raw materials supplier. With no industry to demand large transport volumes, railway transport systems are superfluous is the hidden agenda keeping Africa underdeveloped. There must be no 'dark ages' for the African continent. No people of any nation must be pushed into zero-growth practices and ideologies. No longer must there be a system of unbalanced development, and ethnic divide, a combination of which threatens peace and development. The World Bank position can be likening to British colonialist domination imposed an artificial backwardness on many nations and their people. This caused both an abnormal stagnation of socio-cultural-economic underdevelopment or retrogressions.

Currently, the continent's greatest deficits are leadership, human capital building and commitments of transcending from underdevelopment to development. New thinking, new think-tanks and a progressive human capital development should form the foundation of walking the change. This requires carving a new niche in the continent's policy environment, of which the New Partnership for Africa's Development (NEPAD) through its African Peer Review Mechanism (APRM); Africa's Charter on the Values and Principles of Public Service Administration in Africa; African Charter on Democracy, Elections and Governance among others that craft a new road map of governance and development to better achieve quality livelihood for the people. Transforming the livelihood of the people entails structurally transforming its economies to generate employment, increase incomes and enable industrialization. Many economies are still largely agrarian and Africa still accounts for less than $2 \%$ of global manufacturing exports, a stark comparison to Asia close to $70 \%$. The continent needs to pursue a strong, comprehensive and aggressive industrialization agenda, backed by deepening regional integration which is underpinned by a new form of African leadership providing clear vision as well as mobilizing al segments of society behind the development imperative. In this regard, the continental vision Agenda 2063 of the AU and the creation of Africa's own development goals focused on Africa's priorities. African solution to African problems requires developing an African Development Goals in line with the ongoing discourse of Sustainable Development Goals with Africa's specificities. The time is ripe to leverage these favourable economic trends, while also paying attention to the current megatrends; namely, (i) Africa's population getting younger; (ii) Africa's rapid urbanization; (iii) the spread of ICT's creating opportunities; and (iv) impact of climate change (Lopes, 2015:8-10).

Landlocked, resources deficient poor and other countries suffer from the same patterns of trade since time immemorial and under the canopy of 'cultural imperialism' and other refuse of western colonial office. The Europeans were mercantile - setting up bases along the coast, making forays into the interior to obtain whatever was of worth which they later exported to Europe. Africa provided an invaluable source of raw materials for heir industries - gold, diamonds, ivory, slaves, tea, sugar, coffee, hardwood etc. The continent became the land of great opportunity - where fortunes could be made by any one sufficiently determined to do so. Thus, Africa has been 
central to and will continue to be essential to the vitality and growth of the global economy. Unless Africans control their resources they cannot make progress. Africa can never transition from poverty to wealth unless they move from export of primary products to the creation of industries. That is why Africa beginning from Ghana was talked out of the industrialisation agenda. In short, western agenda was based on a strategy of taking African eyes out rendering it impossible for the continent to find and map out the right compass for its transition. The strategic approach was maintaining the continent as a raw material exporting entity and market for western products.

\section{Discussions and Analysis}

To begin with, Africans must fight for economic independence with the same zeal they fought for political independence. They draw examples from Asian countries. A new mindset is imperative. There is need to assimilate western technologies with African cultures, and move away from the idea of finished goods syndrome. Second, there is the lack of a political will to create a new body of knowledge works in the African society. Third, there is a gross lack of genuine public-private partnership in the continent's development agenda. African governments give little essence to supporting the private sector. There is the strong adherence to state-owned enterprise, which unfortunately is the avenue for corruption and of waste of State funds. Apparently, not all state enterprises promote corruption and the waste of resources. You can find private enterprises that promote corruption and waste of national resources.

Of course, there is the fear that the private sector seems to owe allegiance to the government. Therefore, the continent needs a strong indigenous private sector which should equally be void of party politics influences. The World Bank Structural Adjustment Programme (SAP) did a lot to destroy the economic growth of the continent. This is enough reason for changing existing course. The only magic wane is digging deeper into the secrets why the West with no natural resources is developed and Africa with abundant resource is not developed. The second is learning from best practices as provided by China and the Asian Tiger Nations. It is time for the emergence of a 'developmental state model' whereby the government controls, manages and regulates the economy on the continent. The Chinese economic model of success resonates with the Ethiopian current economic situation, given that China has gone through similar growth in recent history. Thirdly, to sum-up courage, build a new political will to change and grow

Apparently, the challenge Africa has - weakness and threats - looked at these critically and objectively are actually strengths and opportunities. For example, infrastructure is a limiting factor but it is also an opportunity for local and external investors. Therefore, weaknesses and threats can and should be converted into strengths and opportunities. It shows that Africa is on the winning side needing good governance, proper management nexus and determination to convert weakness into strength and threats into opportunities. Across Africa are lots of potentials for growth and behind the slums of every capital are ticked millionaires who can and should invest properly to change the face of the continent. Clearly, there is a lot that needs doing - and no doubt plenty of money to be made doing it which equally trickles down into improving the livelihood of the people.

Africa remains vulnerable due to a number of interrelated inherent factors some of which have been discussed. Based on the reality that the continent holds most of the world resources, both the PESTE and SWOT create basis for reconsidering its current Eurocentric developmental approach and to embrace a progressive Afro-centric developmental agenda. The strength and opportunities of the region is clear. This gives it the structural basis for adequately addressing prevailing weaknesses and threats. From the paper, the weaknesses and threats are indentified as poor governance, poor leadership, poor human capital development, exclusion and inappropriate utilisation of resources, among other factors. Poor institutional construct and underdeveloped infrastructures impedes the sustainable transformation of the region into an economic powerhouse region. The need to invest in elevating the infrastructures of the continent cannot be exaggerated. Africa should take advantage of Gerschenkron (1962) 'late-comer advantage'; exploit its existing strength and opportunities to adequately address prevailing weaknesses and threats. 


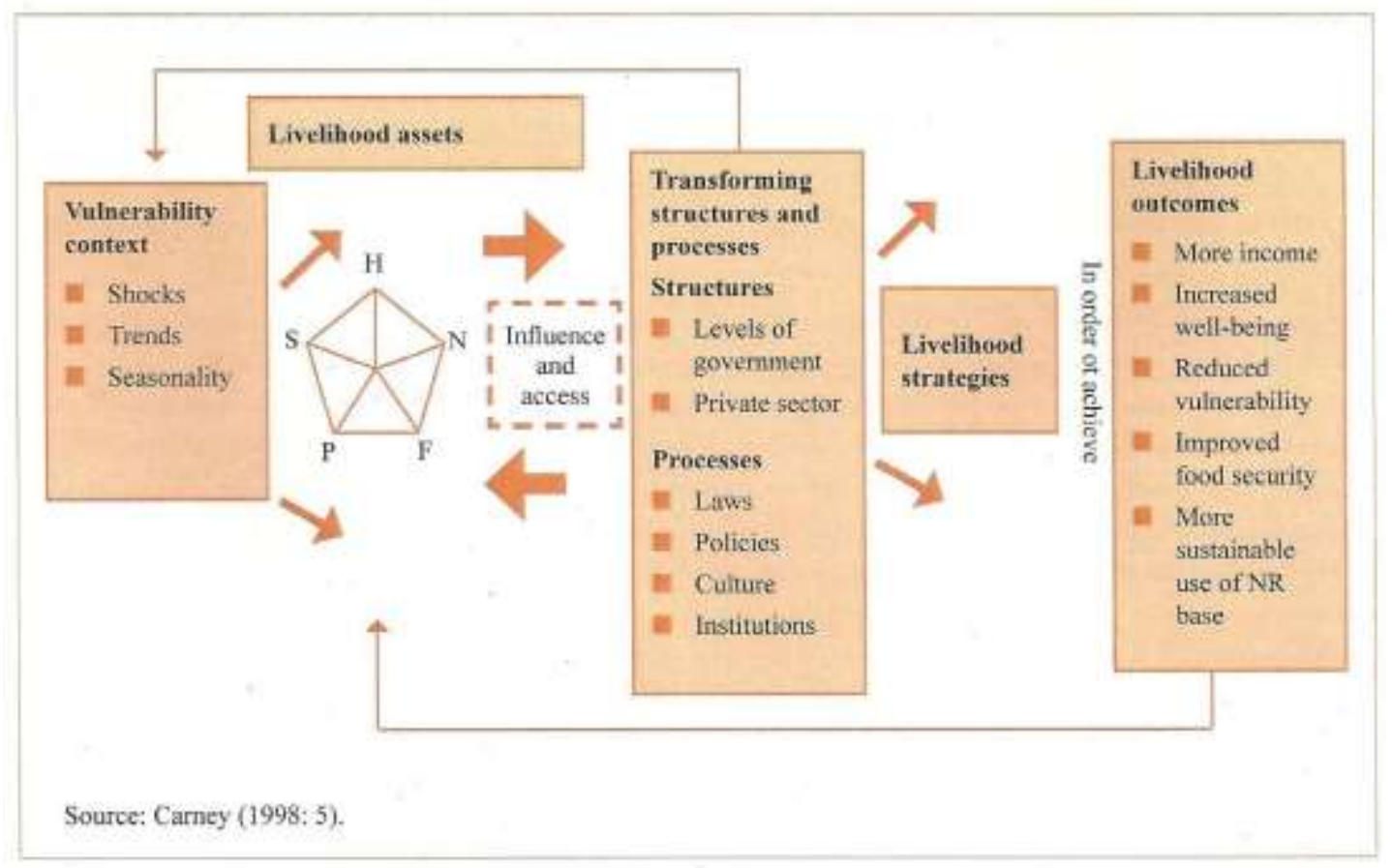

Figure 5. Sustainable Livelihood Framework

This calls for comprehensive and concerted action plans, for example, AU 2063 Agenda, national development plans, which can best be unsurpassed technological knowledge and wisdom of its people. When the resources of the people are depleted, the people must make the transition to a technology-based economy as the only way forward in improving the livelihood construct of the people. Fig 5: Provides the way forward in changing the face of and lives of the people. Within these approaches (SPETEL, SWOT and Late-comer Advantage) lie the issues of financing these infrastructural developments. That is another area for research and discourse. What is important now is linking the coastal states and landlocked countries, industrialise, create more jobs and improve on the welfare of all citizens. Take the case of Ethiopia, for example. As a landlocked country, Ethiopia relies heavily on Djibouti and Kenya for access to the sea. Today, it takes several days for freight trucks to haul containers from the port of Djibouti to Addis Ababa. But when the refurbished electric railroad connecting the two cities opens in 2016, it will reduce transport costs and cut delivery time from four days to just ten hours (Tafirenyika, 2015:4))

Creative and integrated development signifies changing the way one thinks and acts as well as through a constructive combination of the PESTEL and SWOT approaches. The significance of these approaches is that it correlates with the fundamental aspects of sustainable human progress, creating room for certain mechanisms to spot their strengths, weaknesses, opportunities and threats promoting or retarding their development related activities. With this, African countries are exposed to mastering the issues underscoring their transformation by abstract that aspect of his/her creative behavior that correlates with successive advances in mastery of the transformation process. The various institutions or mechanisms provide the needed platform of gagging which way to follow that brings ultimate benefits to society.

This also creates the structural basis for transforming the minds of the people, building economic development and technological progress and foster consciousness for sustainable development related activities that promotes sustainable livelihood for all. Sustainable development goals and progress cannot be attained in an environment permeated with cultural and political barbarism, unrest and wars among African states. The continent cannot sustain development via technological barbarism. Development can only progressed through a well coordinated input mechanisms and structures that improve income, well being, reduced vulnerability and insecurity, improved food, health, shelter security, education, among others; where there is respect for the rule of law, good governance, strong institutions not individuals and where there exist harmonious relationship between the state, civil society and the private sector. 
Currently, African countries are vulnerable to western manipulations. Therefore, levels of state and private sector interface are important for promoting livelihood strategies and constraining some of the vestiges of western imposed transformation nexus that inhibit the sustainable development of the continent. Some of these issues are depicted in Fig. 3: Sustainable Livelihood Framework which also forms the holistic basis for a comprehensive analysis. A new mindset is imperative that should usher constructive reconstruction in 'attitude, behavior and conduct' (ABC) at all levels of society, government and the private sector and as the touch-light to livelihood strategies leading to quality livelihood. Opening up the interior would lead to the industrialization of the region, which in turn would help transform and strengthen their economies. The lack of competitiveness of African manufacturing and the extent to which the scope for domestic value addition is left untapped are epitomized by the cotton's trade in raw materials. For example, follow the Economic Report on Africa by the UN Economic Commission for Africa (2012), while Africa accounted for about $16 \%$ of global cotton exports in 2012, only $1 \%$ of these exports, or about US\$400 million, was cotton that had been processes into fabrics. During the same period, the continent imported US\$0.4 billion worth of cotton and US\$4 billion of cotton fabrics.

The World Bank approach to education was and is destructive, laying strong emphasis to the arts and seeing technical, vocational as having no use to the continent. The International Monetary Fund (IMF) focused on education but ignoring vocational and technical training as the prime driver for change. General education focuses on reading and writing, but this does not take the continent anywhere in terms of development. The continent has failed to utilise knowledge and technology for its sustainable transformation. Knowledge and technology should propel creativity, innovation and entrepreneurial development as the underlying factors for transforming the continent. Looking back at history, with Africa as the cradle of civilization, the centre of university knowledge, and building on the indigenous knowledge of the people, the developing African should watershed itself in these words; 'because of the progress I bequeathed to my posterity to build upon, I ensure that my ancestors have not lived for nothing.' Let us distinguish the essence of that matter in our contemporary development trajectories.

However, Africa can leapfrog into a new brave world by taking a long-look at the rise and fall of Timbuktu. Timbuktu as the first centre for university education in the world fell; Africa has fallen but can rise again. Men and women of wisdom are shinning torches in our darkness; they are torches that will guide us out of our ignorance. Stated differently, the greatest intellectual giants Africa has produced have emphasized on this. For example, Nnamdi Azikiwe (Nigeria) declared some years back; 'show the light and the people will find their way'. Kwame Nkrumah (Ghana) noted that 'socialism without science is void;" and Philip Emeagwali (the Nigeria computer wizard), adding his voice notes that "democracy without technology is void.' Failed states exist because leaders make wrong decisions and the people accept this situation without complaining or request political responsibility to these leaders; for example the ongoing situation between Southern Cameroon and La Republique du Cameroun. Looking forward to another 50 years, of democracy and leadership in Africa plays a vital role in turning what could be seen as a curse into blessing for the transformation of the continent. The wealth and progress of the future of the continent will be derived from developing its intellectual capital (New African, No.500, November, and 2010:97).

That intellectual capital will give added value to the natural resources potentials of the continent in such a way that neither landlocked nations nor nations with access to the coastal region should suffer. No part of the continent should be left behind. The Eurocentric agenda is the 'route of death' for Africa. The progressive Afrocentric strategy provides the road map for Africa's sustainable development goals and development for the welfare of the people. It gives them the will, resilience and strength from rising from the aches of underdevelopment, exclusion, exploitation and poor livelihood. Africa must produce an elite and think-tank corps, not in the sense of a privileged stratum squatting on the shoulders of the less favoured; but an elite of servants, and elite of the dedicated modern agents providing the leadership and sense of direction and new vision for the continent. Only through such a vision can the continent can successfully unlock the continent's economic heart. To quote Patrice Lumumba (1961), 'Africa will write its own history, and in North and South that history will be seen to be one of glory and righteousness,' significantly contributing the sustainable welfare of all citizens. The decision taken by the United Nations in 1989 in declaring 20 November as Africa Industrialisation Day with the goals to mobilize the commitment of the international community to the industrialisation of Africa should be taken seriously in order to transform and strengthen their economies. According to the ECA (2014) the continent must establish stronger institutions and adopt effective measures to enhance structural transformation. In short, deliberate and smart trade policies and practices would lead to the much-delayed industrialization of Africa

The paper has briefly spanned the continent's status of underdevelopment, identifying its struggles, successes and failures. So far the continent faces serious challenges. Attending comprehensively to these issues means, Africa can still raise to greater heights. Africa remains the land of great opportunity, even though, for now, the continent's 
geography has not been kind to landlocked states. The paper set out to elaborate and prescribed some solutions to the plight of landlocked states and the industrialisation of Africa in general; it also had the mission to sharpen the judgement and perception of those forces concerning the right and the wrong concepts of development. Therefore, the paper calls on African governments and its people to exercise political will and courage as well as take the right steps to seek solutions to the problems of its underdevelopment through restructuring its governance system and leadership style and change the management and control of the economy and improve the education and the health system by all African States. A progressive Afrocentric approach is strongly recommended. Any other approach based on short-term considerations would in the long-run operate to the long-run political and economic detriment of Africa. This not what Africa of the $21^{\text {st }}$ century and beyond wants? Africa wants leadership with bold ambition and a clear vision for sustainable quality livelihood for its citizens. African governments must pay serious attention to improved political space, access to media, viability of opposition parties, policies and politics of inclusion, rule of law and civic education and solidarity.

The process in which this paper has engaged us is no mere economic-development, not merely a remedy for the hazards otherwise threatening the continent in this time. We are engaged, if we see that matter rightly, in a battle to finally solve the problem of the 'hinterlands'. The paper has guided us through the dilemma of a landlocked society and the overall issues of underdevelopment. And to place the present and future order of the continent under the rule of the 'Grand Design' of a strong, united and developed Africa by citizens especially consciousness of the development of the creative potentials of the individual mind for the common good. For this condition we must assign to our mind the function of developing a 'watcher' who watches the 'watcher' and to optimally optimise scientific and technological advances for the transformation of the continent. Development is not just a common transformation. It also entails liberating the energies of the people; a country cannot grow without adequately providing basic freedoms and needs. The entre system and the entire survival over time could be questioned because the state has created a democratic society that aspires for a brighter future and wellbeing of the people.

\section{Conclusion and Recommendation}

African solutions to its predicament now demands urgent and radical measures. The continuation of a Eurocentric agenda for the continent implies the continued danger of irreversible damage to the continent. On the other hand, a progressive Afrocentric approach requires the political will which must be mustered in Africa by Africans and the Diaspora to engender a rapid accumulation of industrial capital to advance the continent. In this connection, this paper calls for political courage from all Africans and from the developed political, financial, and economic leaders to promote a New World Economic Order for global development, peace and stability. An African solution now demands urgent and radical national and global measures. The paper presents a blueprint for the sustainable development goals of Africa, by looking particularly at the plight of landlocked countries and Africa in general. The failure of government to address fundamental problems makes natural resource to be curse rather than a blessing to the people.

First, the paper attempts to re-interrogate the deepening crisis of the continent/s development saga. The continued underdevelopment of the continent is attributed to poor leadership, governance and the misuse of natural resources and the mismanagement of the economy. That landlocked territories suffer most as this adds to their cost bills, the general tendency is that of poor leadership and inadequate infrastructures across the continent. It is imperative correcting the flaws of the past to be well equipped to address the present and face the challenges of the future. Therefore, African governments through a progressive Afrocentric approach and from holistic perspectives should champion a new sustainable development agenda to improve on the welfare of the people. The big challenge the continent faces is that poverty is still immense and unemployment is still high. Growth has to bring with it benefits to community. Africa must get its act together and rightly too.

Secondly, African governments are obliged in developing appropriate policies and institutional changes and adaptation technology to the character of each region. The squandering of opportunities, coupled with subsequent development as well as excruciating poverty and general conditions of living, accounts for the new form and character of frustration and the wave of migrations from the continent. This has become more devastating and worrisome under the nascent democracy. The trend, form and character of destructive frustration in the continent only attest to the failure of state (Asonganyi, 2015) and responses to the problem. There is, therefore, an urgent need for fundamental overhaul of the state of governance and resources use. This also requires change in leadership style as well as a strong call for a new mindset among the population. It was Friedrich Last (1841) who noted that 'the nation creates its productive forces out of the mental and physical powers of its individuals'. This statement is a wake-up call for Africa to reinvent, reconstitute and reshape its development trajectories. Africa should draw 
valuable lessons from this statement and forge ahead with its transformation nexus. In other words, '2063 should not be a dream. Africans have the means to achieve AU objectives. All the continent needs is building self confidence. Africa will not be saved or developed by an international committee. It must stop begging and dependent on grants. In addition, the illicit flight of capital must stop' (Nkosi, 2015:20). Only Africans can build up Africa. It involves the participation of all. Each individual should contribute his/her quota for a brighter future awaits the continent. The potential power of every African must be harnessed.

Thirdly, the state, civil society and the private sector need to articulate forward looking policy strategies to ensure that the best results arising out of the exploitation of the natural resources base are used in improving the sustainable welfare of the citizens. This means sustainable investments in human capital development, institutions building and infrastructure development. The Afrocentric agenda should be geared towards ending poverty and hunger and to achieve sustainable development through promoting inclusive economic growth, protecting the environment and promoting social inclusion. Africa is now a late-comer to development but with many advantages provided by advances in science and technology providing fundamental breakthroughs that cuts down Rostow's stages of development. Bold ambition and political assertiveness is what the continent needs to become a capable developmental state. It is time the continent flexes its economic muscle by giving comprehensive added value to its vast natural resources potential. They need also to come up with innovative financial products and establish effective and efficient national and regional financial institutions and services to sustain its related development activities for the overall wellbeing of the people.

Fourthly these competing narratives will continue for years to come until the continent is able to get its strategic approach more people-oriented, coordinated and coherently implemented for the overall welfare of society. What can be said with some degree of certainty is that the continent is gradually moving towards democratic governance regime structure. What are still lacking are servant visionary leadership, and a radical change in mindset by the population to be proactive citizens and to own their development. The continued dilemma of landlocked African countries has now generated a new kind of debate for the continent to deal rigorously and constructively about its resources and of its use for improving on the welfare of the population and in line with UN Agenda 2030 and AU Agenda 2063.

\subsection{Recommendations}

- Addressing the root causes of the continents underdeveloped status requires a constructive rethinking in the governance and leadership construct of the region;

- Civil society and the private sector must develop a new mindset for the sustainable transformation of the continent.

- Only a comprehensive focus on good governance at all levels, that is efficient and people-oriented can make positive changes in the lives of the people;

- Reduce inequality within and among countries; as well as promote inclusive and sustainable economic growth, full and productive employment and decent work for all;

- Empowerment of the female gender as well as ensuring the youths are put into useful employment spree as the life-wire for Africa's development;

- Ensure economic integration within and? between states; regional integration should be a win-win project for all its stakeholders beyond the tokenism of solidarity and charity.

- Africa should intensify its ongoing efforts to diversify the economy, build infrastructures, and connect with the interior or landlocked areas to rebuild the economy and welfare of the people.

- There is an urgent need to promote peace and inclusive societies for sustainable development, provide access to justice for all and build effective, accountable and inclusive institutions at all levels.

\section{References}

African Union. (2011). African Charter on Democracy, Elections and Governance, Addis Ababa, Ethiopia.

African Union. (2011). African Charter on the Values and Principles of Public Service and Administration, Addis Ababa, Ethiopia.

Ake Claude. (1996). Democracy and Development in Africa. Brookings Institution, Washington DC USA.

Agbu, Osita. (2005). "Oil and Environmental Conflicts", in Saliu, Hassan A. (ed.) Nigeria Under Democratic Rule, 1999-2003, 2, Ibadan University Press, Ibadan, Nigeria. 
Asonganyi Tazoacha. (2015). Cameroon: Difficult Choices in a Failed Democracy [Memoir) NGT Publishing, Madison, USA

Brandmann Hans. (1980)."Opening Address to the FEF Conference on the Industrialisation of Africa", Fusion Energy Foundation (1980) The Industrialisation of Africa Campaigner Publications, Wiesbaden, Germany.

Brock Joe. (2015). "Shaking Up African Aviation”, The New Age, 17 September 2015, South Africa, 16.

Burke, John. (2014). Introduces PESTEL and SWOT Analysis, Northumbria University, Newcastle, England.

Carney, D. (ed.). (1998). Sustainable Rural Livelihoods: What Contribution Can We Make? UK Department for International Development (DfID).

Chhotray, V, \& Hulme, D. (2009). Contrasting Visions for Aid and Governance in the $21^{\text {st }}$ Century: The White House Millennium Challenge Account and DFID's Drivers of Change. World Development, 37(1), 36-49. https://doi.org/10.1016/j.worlddev.2007.11.004

Commey Pusch. (2015). "South Africa: Looking into the Crystal Ball: New African, No. 553, August/September 2015, London, 48-50.

Djanie Akua. (2015). Why I Am Not Feeling Proudly Ghanaian, New African No. 553, August-September 2015, London, 46-47.

Dowden Richard. (2010). Africa: Altered States, Ordinary Miracles, Public Affairs, New York, N.Y. UAS.

Economic Commission for Africa (ECA). (2014). Dynamic Industrial Policy for Africa Addis Ababa, Ethiopia.

Forje W. John. (2011). State Building and Democracy in Africa. A Comparative and Developmental Approach A CARAD Publication/Nova Science Publishes Inc, New York, USA.

Fusion Energy Foundation. (1980). The Industrialisation of Africa, Campaigner Publications, Wiesbaden, Germany.

Gerschenkron, A. (1962). Economic Backwardness in Historical Perspectives The Belknap Press of Harvard University Press, Cambridge, USA.

Grindle, M. (2002). “Good Enough Governance: Poverty Reduction and Reform in Developing Countries', paper prepared for the Poverty Reduction Group of the World Bank, Kennedy School of Government, Harvard University, Boston, MA.

Joseph A. Williams (ed.). (2010). Politics in China. Oxford University Press, Oxford, UK

Juma Calestous. (2015). "Enterprises as Innovations Schools", New African No.553, August-September 2015, London, 68-69.

Kabukuru Wanjohi. (2015). "Post-2015: In Whose Hands is Africa's Future:" New African No.553, August-September 2015, London, 10-16.

Knight Barry, Hope Chigudu \& Rajesh Tandon. (2002). Reviving Democracy: Citizens at the Heart of Governance. The Commonwealth Foundation, Earthscan Publishers, London.

Legum, C. \& Zartman, I.W. (1979). Africa in the 1980s (1980s Project - Council on Foreign Relation) McGraw-Hill Books USA,

Lopes Carlos (2015). “It Is Africa's Time”, New African No. 554, October 2015, London, pp8-10

Mashamaite Moss (2014) The Moving Finder Writes Vol. 2, Chatworld Publishers, South Africa.

Muchie Mammo (2015) "Why Pan-African Education Should be Promoted", New African, No.553, August-September 2015, London, 24-25.

New African. (2010). "Africa Can leapfrog Into the Information Age”, New African, No.500, November 2010, London, 97.

Nkosi Ntombi. (2015). "Shaping Africa's Future” The New Age, 17 September 2015, South Africa, 20.

Nye S. Joseph. (2010). The Power to Lead. Oxford University Press. Oxford, UK.

Omotola Shola. (2006). The Next Gulf? Oil Politics, Environmental Apocalypse and Rising Tension in the Niger Delta. Occasional Paper Series, 1(13), 2006 ACCORD, Durban South Africa. 
Rothstein, Bo \& Teorell, Jan. (2008). What is quality of Government? A Theory of Impartial Government Institutions. Governance: An International Journal of Policy, Administration and Institutions, 21(2), 165-90. https://doi.org/10.1111/j.1468-0491.2008.00391.x

Sachs D. Jeffrey. (2015). The Age of Sustainable Development. Columbia University Press, USA.

Sofaniadi Safrinal, Rusmandi \& Aniessa Delima Sari. (2015). Protect, Adapt or Relocate? Responding to Climate Change in Coastal Indonesia, Working Paper Series 14:2015, IIED London.

Stuart Elizaberth. (2015). China Has Almost Wiped Out Urban Poverty. Now It Must Tackle Inequality. Overseas Development Institute, (ODI) United Kingdom.

Tafirenyika Masimba. (2015). The Changing Face of Ethiopia. Africa Renewal, 29(2), August 2015, United Nations, NY, 4-5. 